Anna DUNAY, Zoltán T. NAGY, Csaba Bálint ILLÉS

\title{
3.1. ORGANIZATIONAL CULTURE ASSESSMENT - A CASE STUDY OF HUNGARY AND AUSTRIA
}

\begin{abstract}
Summary
In this study, we compared the organizational culture of two companies of similar size, which are both working in the chemical equipment manufacturing market. The comparison is based on interviews of the corporate executives and the analysis of the data gathered by questionnaire of Competing Values Model. Based on these data we observed that the Hungarian company's organizational culture shows duality, because at the manufacturing departments of the company a dominantly hierarchical organizational culture may be found, while among white-collar workers the market structure is typical. The organizational culture of the Austrian company is uniformly hierarchical in the entire organization. Both company's organizational culture is significantly different when compared to those structures which are described in the literature sources characterizing the two countries. We clearly found the different effects of the Austrian and Hungarian national cultures in the organizations, however, the effects and influence of the strict and uniform EU regulations of the investigated industrial sector were represented even more strongly. These regulations seem to drive the two company's organizational culture in the same direction.
\end{abstract}

Keywords: national culture, organizational culture, Competing Values Framework

\section{Introduction}

Nowadays, under the increasing competitive circumstances, the achievement of the desirable organizational efficiency attracts the interest of researchers and market players as well, and organizational culture is one of the key factors. Organizational culture is important to the practitioners, because it affects all aspects of interrelationship both intra-organizational and inter-organizational.

In the daily operation of small and medium sized enterprises (SMEs), especially in Eastern Europe, most managers are not able to find enough time to deal with organizational culture issues, but this does not mean that organizational culture does not exist. Organizational culture develops from the foundation of a company and it is influenced by external factors like national culture, industrial sector and technology and by internal circumstances such as company size, management strategies, decisions and leadership style. It is a continuously changing aspect of an organization, in which managers can instantiate changes to better suit their business strategy (Bakacsi, 2004, p. 223). However, organizational culture is difficult to modify as it is developed during a long period. Companies must think critically about that how they will run their business, because initiatives should be consistent with the organizational culture (Abbett, Coldham and Whisnant, 2010).

Many researchers and leaders underline that organizational culture as an important factor of the successful operation. However, only a few researches on organizational studies were resulted by the findings of case studies, most of them are based on 
empirical evidence. Applying a practical framework to this issue would contribute to a valuable insight into the real organizational culture issues, by which our existing theoretical and empirical knowledge could be complemented. Therefore, in our research, we compared the organizational culture of two companies: one from Hungary and one from Austria.

\section{Literature review}

According to Hofstede and Hofstede (2005), national culture is the collective programming of the mind distinguishing the members of one group or category of people from others. The six dimensions of national culture are individualismcollectivism; uncertainty avoidance; power distance (strength of social hierarchy); masculinity-femininity (task orientation versus person-orientation); long-term orientation and indulgence versus self-restraint.

It has been proven in previous researches that national culture has a strong influence on the organizational culture of an enterprise (Kertai-Kiss, 2014). National cultures were studied extensively in the past decades. Based on the information of the Hofstede Centre (2015) one can summarize the differences and similarities of the national cultures in Hungary and Austria. Based on this model, we found that the two cultures are quite similar in three aspects: Masculinity, Uncertainty Avoidance and Long Term Orientation. There is a gap between the Optimism of the two countries, Austria being explicitly more optimistic. Individualism is more typical in Hungary and particularly Power distance is much higher. These differences may derive from the historical differences of the $20^{\text {th }}$ century: Austria was among Western countries, while Hungary was a part of the Eastern bloc. Interestingly, while according to the Hofstede model, Austria has the lowest Power Distance Index globally and Hungary is in the middle range.

According to Dittrich et al. (1996), national cultures of Western Europe and the former socialist countries are getting closer and closer to each other owing to globalization and of course, the fall of the Iron Curtain.

Dimitratos et al. (2011) examine how national culture values affect strategic decisionmaking processes of internationalized firms. The findings of the study prove that the national culture of the focal firm may have a strong influence among internationalized small and medium-sized firms. It verifies that the examination of the national culture cannot be ignored.

Cheng et al. (2007) pointed out that evidence suggests that the encountered problems of companies mostly are not technical in nature; they are usually 'soft' problems, such as having an organizational culture that is not implicitly or explicitly supportive. Therefore, it is essential to deal with organisational culture issues.

In the international literature, there are many definitions for organizational culture. According to Aktas et al. (2011, p. 1561.) it is 'a model of norms, values, beliefs and attitudes which affects organizational behaviour'. According to Kordshouli et al. $(2013$, p. 2840) 'organizational culture can be defined as values, beliefs, principles observed as a framework for systems and managerial activities'. One can agree with the authors that 'one of the essential factors on reaching success within organizations 
is to learn more about organizational culture, to direct and to improve it towards favourite organizational culture' (Kordshouli et al., 2013, p. 2840).

The Competing Values Framework (CVF) of Cameron and Quinn (1999) now is one of the most influential and widely adopted model by both academicians and practitioners, and used to understand better the relationship between organizational culture and the company's performance. The main idea behind the theory is that when all leaders, managers and staff within an organization have a perspicuous sense of their culture, it creates order, continuity, collective identity, commitment, and common vision while reducing organizational uncertainties. This leads to improved organizational effectiveness (Cameron and Quinn, 2006).

CVF describes the organizational cultures in two main dimensions: the internal vs. external orientation, and the flexibility and dynamism vs. stability and control. The different approaches of a given organization towards these values allow the categorization of the companies into four culture types, which are called Clan, Adhocracy, Market and Hierarchy. The main characteristics of the four types are summarized in Table 1.

Table 1: Characteristics of organizational culture types

\begin{tabular}{|c|c|c|c|c|}
\hline & Clan & Adhocracy & Hierarchy & Market \\
\hline $\begin{array}{c}\text { Dominant } \\
\text { character- } \\
\text { istics }\end{array}$ & $\begin{array}{l}\text { Personal, family- } \\
\text { like }\end{array}$ & $\begin{array}{l}\text { Entrepreneurial, } \\
\text { risk taking }\end{array}$ & $\begin{array}{l}\text { Controlled and } \\
\text { structured }\end{array}$ & $\begin{array}{l}\text { Competitive, } \\
\text { achievement- } \\
\text { oriented }\end{array}$ \\
\hline $\begin{array}{l}\text { Leadership } \\
\text { style }\end{array}$ & $\begin{array}{l}\text { Mentoring and } \\
\text { supporting, } \\
\text { parental role }\end{array}$ & $\begin{array}{l}\text { Creative, } \\
\text { innovative, risk } \\
\text { taking }\end{array}$ & $\begin{array}{l}\text { Coordinating, } \\
\text { organizing, } \\
\text { efficiency oriented }\end{array}$ & $\begin{array}{l}\text { Aggressive, } \\
\text { result-oriented } \\
\text { hard drivers }\end{array}$ \\
\hline $\begin{array}{l}\text { Manage- } \\
\text { ment of } \\
\text { employees }\end{array}$ & $\begin{array}{l}\text { Teamwork, } \\
\text { consensus and } \\
\text { participation }\end{array}$ & $\begin{array}{l}\text { Individual risk- } \\
\text { taking, innovative } \\
\text { entrepreneurs }\end{array}$ & $\begin{array}{l}\text { Security, } \\
\text { conformity, } \\
\text { predictability }\end{array}$ & $\begin{array}{l}\text { Competitiveness } \\
\text { and achievement }\end{array}$ \\
\hline $\begin{array}{l}\text { Organiza- } \\
\text { tional glue }\end{array}$ & $\begin{array}{l}\text { Loyalty, tradition } \\
\text { and mutual trust }\end{array}$ & $\begin{array}{l}\text { Commitment to } \\
\text { innovation, } \\
\text { development }\end{array}$ & $\begin{array}{l}\text { Formal rules and } \\
\text { policies }\end{array}$ & $\begin{array}{l}\text { Emphasis on } \\
\text { achievement and } \\
\text { goal accomplishing }\end{array}$ \\
\hline $\begin{array}{l}\text { Strategic } \\
\text { emphasis }\end{array}$ & $\begin{array}{l}\text { Human } \\
\text { development, high } \\
\text { trust, openness }\end{array}$ & $\begin{array}{l}\text { Acquisition of } \\
\text { resources, creating } \\
\text { new challenges }\end{array}$ & $\begin{array}{l}\text { Permanence and } \\
\text { stability }\end{array}$ & $\begin{array}{l}\text { Competitive actions } \\
\text { and winning }\end{array}$ \\
\hline $\begin{array}{l}\text { Criteria for } \\
\text { success }\end{array}$ & $\begin{array}{l}\text { Development of } \\
\text { human resources, } \\
\text { teamwork, concern } \\
\text { for people }\end{array}$ & $\begin{array}{l}\text { Unique and new } \\
\text { products and } \\
\text { services }\end{array}$ & $\begin{array}{l}\text { Dependable } \\
\text { delivery, efficient, } \\
\text { scheduling, low } \\
\text { cost }\end{array}$ & $\begin{array}{l}\text { Winning in the } \\
\text { marketplace, market } \\
\text { penetration }\end{array}$ \\
\hline
\end{tabular}

Source: own compilation based on Aitken and Higgs (2010), www.ocai-online.com, Cameron and Quinn, (1999)

Several research aimed to measure the differences in the national cultures and organizational cultures of Hungarian and Austrian companies (Szöke, 2014), but all of these use data from different industrial sectors, from manufacturers to service and consulting companies. The information on the cultural aspects of these companies is therefore also influenced by the differences of the organizational cultures, which can be attributed to different industrial sectors. In addition, these researches considered 
only the cultural aspects based on the answers of the general managers and not that of the different managerial levels or departments of the organization.

In these general researches of the organizational cultures of Hungarian companies, we found that the Hierarchy culture type is dominant, Clan and Market culture types are equally represented and Adhocracy culture type can be found only in $10-16 \%$ of the investigated companies. (Costa and Bogdány, 2013; Gaál et al., 2010)

In the literature concerning the Austrian companies an interesting comparison was made between the Austrian and Australian construction firms, which showed that in this sector the dominant organizational culture type is Market (Lorenz and Marosszeky, 2004).

Acikgoz and Gunsel (2011) investigated the interrelationship between organizational climate and team innovativeness. The findings provide empirical evidence in support of the relationship between innovative vision and managerial support dimensions of climate and team innovativeness. Moreover, the study showed that there is a greater relationship between innovative vision, management support and team innovativeness when environmental uncertainty is greater. Aktas et al. (2011) concluded that organizational culture has an impact on job satisfaction, job efficiency, employee commitment and cooperation. Reimann et al. (2012) also argued that employees are among the forces that drive firms to superior performance.

Koufteros et al. (2007) also found strong positive relationship between level of customer orientation and supported values relating to beliefs on management control, beliefs on working with others, and beliefs on making decisions, which are global. Regarding the increases in customer expectations and competition, the authors stated that manufacturers might need to be responsive and flexible in order to stay competitive. Their findings are consistent with the literature on innovation and organizational theory.

The lack of adequate climate of organization will have negative and strong effects for both employees and organizations. According to Erdil and Ertosun (2011) managers generally take competitiveness of employees into consideration and they believe that this will increase productivity. This attitude is beneficial in the short term but in long term may create decrease in productivity, as employees may feel loneliness in work. Managers should not think in short terms. In addition to this, authors highlighted that synergy among employees will increase willingness to learn and creativity, and a result of this, productivity is another important and related component. Summarizing the authors' findings, positive social relationships should be supported by managers, by the help of positive work life experience for both employees and organizations, much positive outputs can be gained (Erdil and Ertosun, 2011).

The theoretical proposition of Pernot and Roodhooft (2008) was that the organizational cultural resemblance of suppliers is positively associated with the speed at which the management control system changes in case of changing circumstances. Their longitudinal data provided evidence supporting this theoretical proposition. For example, the higher level of management control immediately fitted the risks increase at the start of production and contributed to sustaining good performance. Thus, manufacturers need to be aware of the own values and should be aware of the influence of supplier cultural resemblance. 
However, in his study he presented a behavioural perspective on organizational culture and contributed to its emerging dynamic aspect. Thus, changing environment conditions, internal and external should be examined.

Linnenluecke and Griffiths (2010) tried to examine whether there are links between organizations that emphasize a certain organizational culture type - characterized by one or more of the four different culture types of the Competing Values Framework and the adoption of corporate sustainability principles. They could not provide links.

\section{Research methods}

The empirical research was carried out by comparing the organizational cultures in different management levels of two similar companies. Both of these companies are medium-sized enterprises which supply specialized equipment for chemical-, mainly pharmaceutical manufacturers. Although they are similar in size, turnover and number of employees, they are not competitors, as they operate mainly in their homeland markets. Due to these similarities, we expected the results of the comparison of the organizational cultures to be less influenced by other factors than national culture. Of course, the differences between the management styles and historical development of the two investigated companies are remaining to be influencing factors.

The cultural diagnosis was started with structured interviews with the managers of each company, which provided qualitative indications of the similarities and the differences of the organizational cultures.

In order to provide a quantitative approach, we have chosen to diagnose of the organizational cultures of the enterprises also by the Competing Values Framework of Cameron and Quinn. (Cameron and Quinn, 1999, 2006), because this model provides means of quantifying culture and has a strong and well-established empirical basis for cultural diagnosis.

Figure 1: The Competing Values Framework

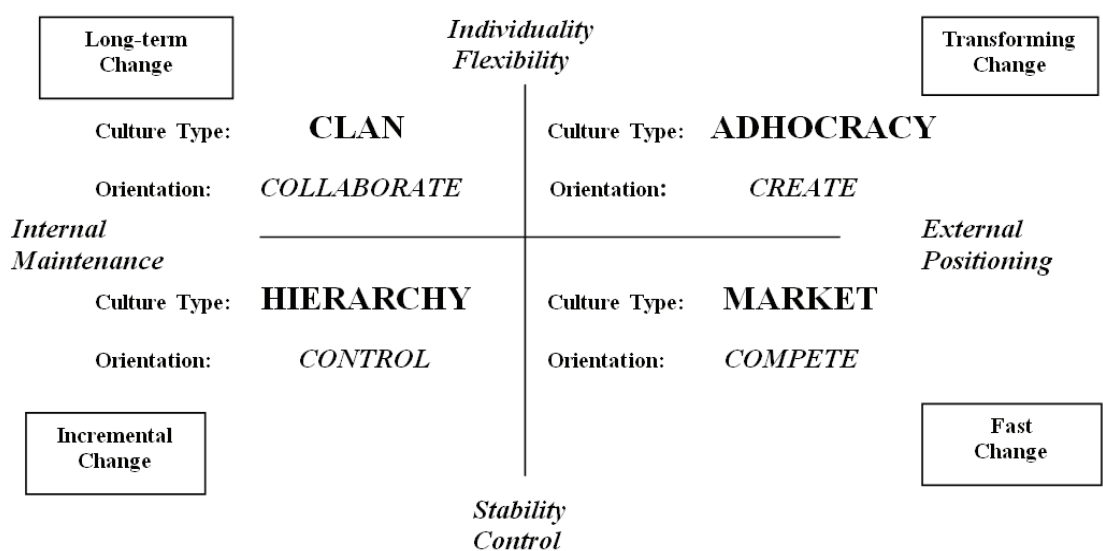

Cameron and Quinn (2006) also published the questionnaire of the Competing Values Framework, which they called Organizational Culture Assessment Instrument, which was used in Hungarian and German translation in our study. Cameron and Quinn (1999) applied an ipsative response scale in which participants must share 100 points 
among the four alternatives describing each cultural dimension. This type of scale could emphasize the differences between the cultural orientations. The peculiarity of this instrument is that it measures the currently experienced and also the preferred culture dimensions, culture types. This allows managers to express if they are not aware, as in most cases, to define the right cultural dimensions for their business strategy systematically.

\section{Research results}

The investigation started with structured interviews of both companies' general managers. The relevant answers showed that the Hungarian company is externally oriented. The results also supported the data of the Hofstede Center (2015) that in Austria Power Distance is lower as in Hungary. The first findings of the research were described by Nagy et al. (2015).

The questionnaire was filled in by $43 \%$ of the employees of the Hungarian and $26 \%$ of the employees of the Austrian company. In both organizations the general managers and all of the middle managers answered, which allowed a distinction of the answers based on management level, therefore we analysed the data in 4 groups: general manager level, middle management level, office workers' level (engineers and administrative staff) and among blue-collar workers.

Firstly, we examined the organizational culture in the different levels of the Hungarian company (Fig. 2).

Figure 2: Perception of organizational culture at different levels of the Hungarian company

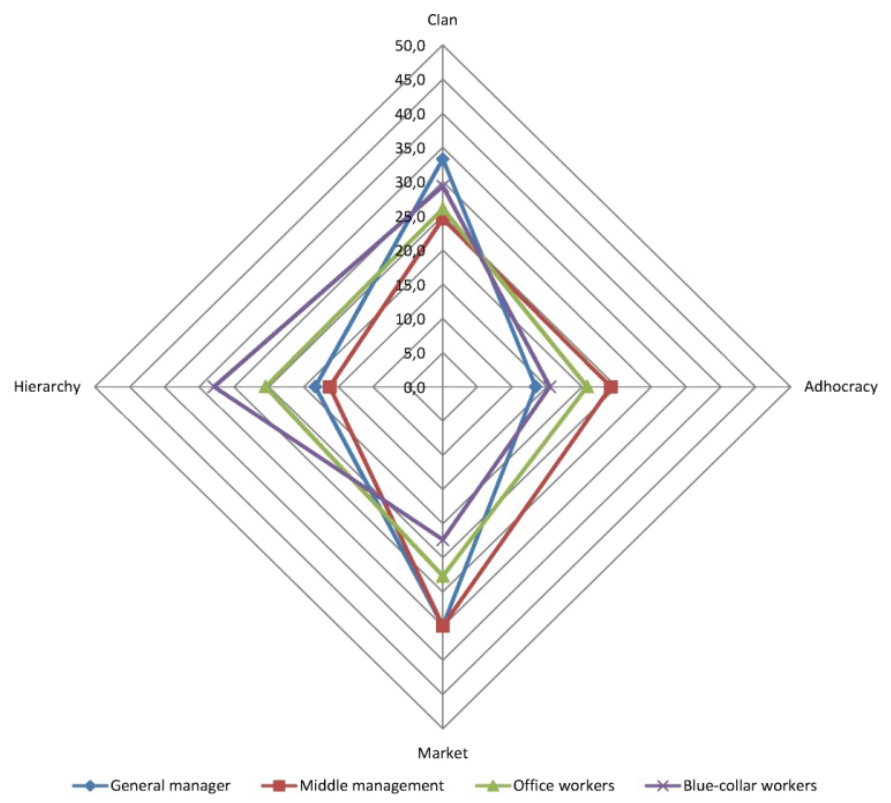

Source: own study, 2015 
In the Hungarian company, we found that Market and Clan culture is dominant in the perception of the general manager and the Hierarchy type is more and more important in the lower levels of the organizational structure. At the level of the blue-collar workers, the Hierarchy becomes the dominant culture.

In the research of Aktas et al. (2011), the culture of Clan was found as negatively related to the organizational environment factor, which emphasizes organizational structure, work in organization, and external competition. The importance of cohesion observed as high for the employees in the Market culture. This implements the significance to the institutional policies and human resources practices, which assure employees to be market oriented and to identify themselves with the institution for this.

Secondly, we moved on the examination of the organizational culture in the different levels of the Austrian company (Fig. 3).

Figure 3: Perception of organizational culture at different levels of the Austrian company

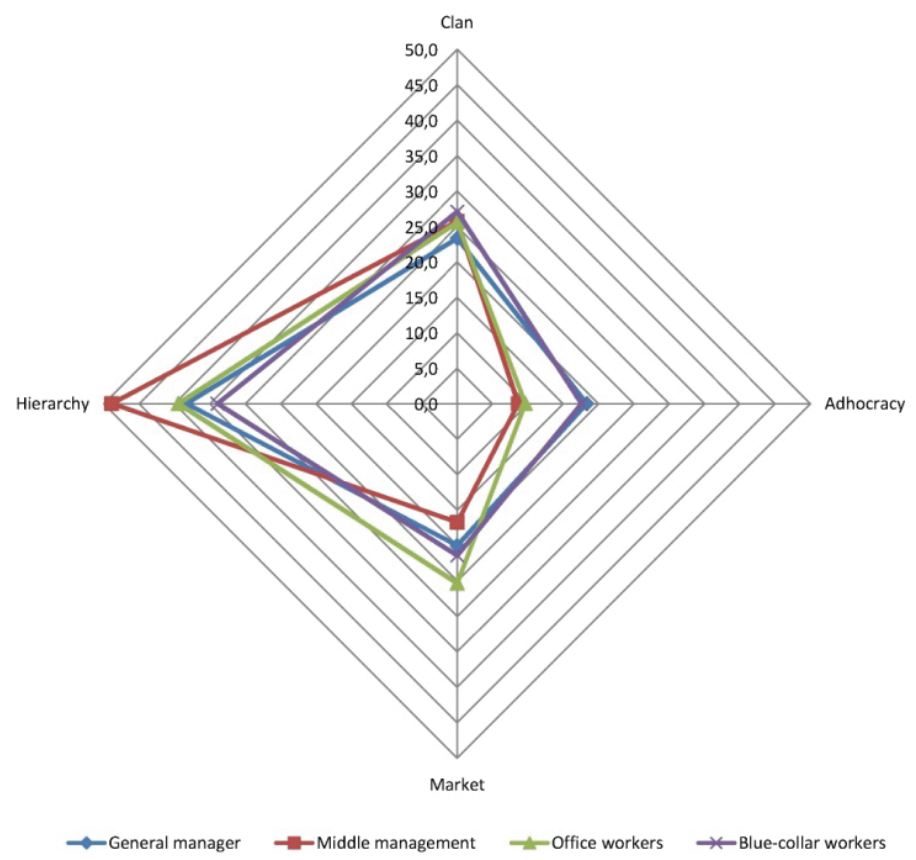

Source: own study, 2015

In the Austrian company, we found that Hierarchy is the dominant culture throughout the entire organization. According to Aktas, Cicek and Kiyak (2011) Hierarchy (and also Market) culture have a strong influence on organizational efficiency.

Richard et al. (2009) examined the role of psychological contracts of the organizational culture to affective commitment as a mediator. They found that Clan cultures positively affected relational contracts and negatively influenced transactional contracts. Hierarchical cultures had a reverse effect. Psychological contract types (relational and transactional) mediated the relationship between organizational culture 
and organizational commitment. Their findings show that a Clan culture is essential for the creation of relational contracts while a Hierarchy culture contributes to the creation of transactional contracts. Their research suggests that if violations of psychological contracts are perceived by employees, the results can have negative effects on the organization. According to the authors, these negative results can then lead to, for example, lower performance. Therefore, it is important that organizations and managers should understand these relationships and how could they manage them most effectively.

Thirdly, we analysed the 'preferred' culture types in both companies (Figure 4.)

Figure 4: Comparison of the preferred culture dimensions

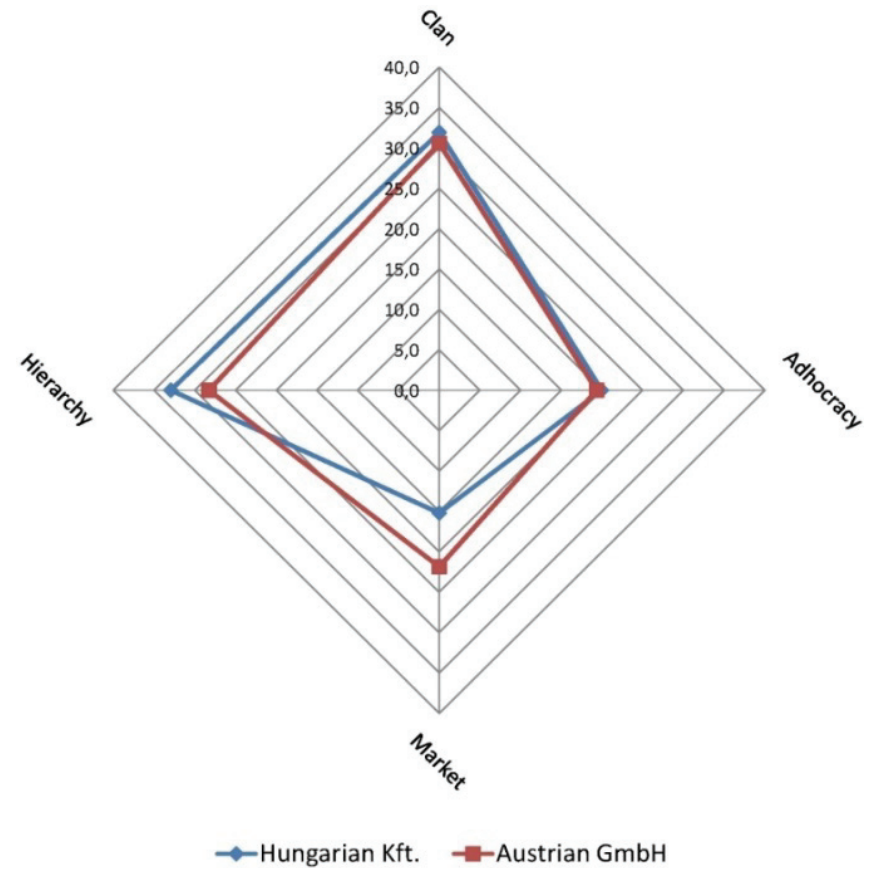

Source: own study, 2015

Based on the results of the comparison of 'preferred' culture types it could be realized that in the Austrian company is more market oriented and in Hungarian company has a more internal orientation where the control would be ideal according to the employees. This means that the differences in cultural dimensions of the two companies might be reduced to a minimum, if the desired changes would take place.

According to the results of Aktas et al. (2011) organizational arrangement, work in organization and external competitiveness, organizational structure and determined job also have a moderator effect on the relationship between organizational culture types and organizational effectiveness, especially for three types of culture: Hierarchical, Clan and Adhocracy. 


\section{Conclusions}

Drawing the conclusions it can be stated that based on literature, it is clear that investigating the effects of organisational culture on the efficient performance of companies is inevitable, because organisational culture has an impact on job satisfaction, job efficiency, employee commitment and cooperation and also on organizational changes, learning, climate, security, motivation, innovation, development etc. Summing up, it has strong impact on effectiveness, profitability and competitiveness of modern industrial organizations. Therefore, business leaders cannot ignore the organizational culture issue.

Although our research is in progress with partial results, these results may allow some speculation and inferences. Firstly, it is interesting to note that the investigated two companies do not show the dominant culture types, which would be characteristic of similar companies in their countries, although a hierarchy type of organizational culture is typical in German speaking countries.

Secondly, it is important to note that these companies have a quite simple organizational structure. Considering that the studied companies are partially owned by their general managers, it is expected that the influence of the managers' personal character is even more influential than in bigger organizations.

The most important finding is, however, that in this uniformly regulated sector, where EU regulations should be strictly kept, Hierarchy type of culture is imposed on the manufacturing departments and this sectorial character is more influential than the differences in the national cultures of Hungary and Austria.

Further investigations in similar companies, possibly in other, - culturally more diverse - countries, would reveal more evidence of the influence of national cultures on the organizational culture.

\section{References}

1. Abbett, L., Coldham A., Whisnant R. (2010): Organizational Culture and the success of corporate sustainability initiatives: An empirical analysis using the Competing Values Framework. University of Michigan, pp. 1-68.

2. Acikgoz, A., Gunsel, A. (2011): The effects of organizational climate on team innovativeness. Procedia Social and Behavioural Sciences 24, pp. 920-927. http://dx.doi.org/10.1016/j.sbspro.2011.09.102

3. Aktaş, E., Çiçek, I., Kıyak, M. (2011): The Effect of Organizational Culture on Organizational Efficiency: The Moderating Role of Organizational Environment and CEO Values. Procedia Social and Behavioural Sciences, 24, pp. 1560-1573.

4. Bakacsi, Gy. (2004): Szervezeti magatartás és vezetés. Aula Kiadó, Budapest

5. Cameron, K. S., Quinn, R. E. (1999). Diagnosing and changing organizational culture: Based on the competing values framework. Addison-Wesley Publishing Company, Reading, Mass.

6. Cameron, K. S., Quinn, R. E. (2006): Diagnosing and changing organizational culture: based on the competing values framework. Revised ed. John Wiley and Sons, San Francisco

7. Cheng T. C. E., Lai K-H, Koufteros X., McDermott C. (2007): Special issue on organizational structure, culture and operations management: An empirical missing link, 106(2), pp. 321-322.

8. Costa, J. P. M., Bogdány, E. (2013): The relationship between organizational culture and the transfer of management, functions and roles in the SMEs succession: A case study between Hungary and North of Portugal. Tourism \& Management Studies, Vol. 9, Issue 1, pp. 121-128. 
9. Dimitratos, P., Petrou, A., Plakoyiannaki, E., Johnson, J.E. (2011): Strategic decision-making processes in internationalization: does national culture of the focal firm matter? Journal of World Business, 46 (2). pp. 194-204. http://dx.doi.org/10.1016/j.jwb.2010.05.002

10. Dittrich, E., Makó, C., Stojanov, C. (1996): Unternehmenskultur, Nationalkultur und Transformation. In: Lang, R. (1996), Wandel von Unternehmenskulturen in Ostdeutschland und Osteuropa, München/Mering, pp. 73-91.

11. Erdil, O., Ertosun, Ö.G. (2011): The Relationship between Social Climate and Loneliness in the Workplace and Effects on Employee Well-Being. 7th International Strategic Management Conference. Procedia Social and Behavioural Sciences 24 (2011) pp. 505-525.

12. Gaál, Z., Obermayer-Kovács, N., Csepregi, A., Antonova, A., Jenei, E. (2010): Clan, Adhocracy, Market, Hierarchy? Investigating Organizational Culture Types and Knowledge Sharing in Bulgaria, Hungary and Serbia. pp. 52-61. In: Uden et al. (eds.) KMO 2010 - Roles and Challenges of Knowledge Management in Innovation for Services and Products. 5th International Knowledge Management in Organizations Conference. Veszprém, Hungary

13. Hofstede, G., Hofstede, G. J. (2005): Cultures and Organizations: Software of the Mind. Revised and expanded $2^{\text {nd }}$ Edition. McGraw-Hill, New York, USA, p. 436

14. Kordshouli, H. R., Baneshi E., Rezaei B. (2013). Depicting favorite organizational culture: An empirical case study. Management Science Letters, 3(11), pp. 2839-2846.

15. Koufteros X. A., Nahm A. Y., Cheng T. C. E., Lai K. (2007): An empirical assessment of a nomological network of organizational design constructs: From culture to structure to pull production to performance. International Journal of Production Economics 106(2), pp. 468492. http://dx.doi.org/10.1016/j.ijpe.2006.08.001

16. Kertai-Kiss, I. (2014): The Fit of National and Organisational Cultures in International Scientific Literature. Management, Enterprise and Benchmarking in the $21^{\text {st }}$ Century, Óbudai Egyetem, Budapest, pp. 301-314.

17. Linnenluecke, M. K., Griffiths, A. (2010): Corporate sustainability and organizational culture. Journal of World Business 45/2010. pp. 357-366. http://dx.doi.org/10.1016/j.jwb.2009.08.006

18. Lorenz, K., Marosszeky, M. (2004): Intercultural Management for International Construction Projects - A Comparison of Austria and Germany with Australia. In: Khosrowshahi, F. (ed.), Proceedings 20th Annual ARCOM Conference, Edinburgh, UK, Vol. 1, pp. 427-436.

19. Nagy, T. Z., Hurta, H., Dunay, A. Illés, Cs. B. (2015) The comparison of the organizational culture of an Austrian and a Hungarian chemical engineering company. In: Proceedings of the 5th International Conference on Management 2015. Management, leadership and strategy for SMEs' competitiveness. Szent István University Publishing House, Gödöllő, pp. 35-39. http://dx.doi.org/10.17626/dBEM.ICoM.P00.2015.p007

20. Pernot, E., Roodhooft F. (2008). The impact of cultural resemblance on management control of supplier relations: Longitudinal evidence in the automotive industry. Vlerick Leuven Gent Management School Working Paper Series 2008/18. pp. 1-58.

21. Reimann, F., Ehrgott, M., Kaufmann, L., Carter, C. R. (2012). Local stakeholders and local legitimacy: MNEs' social strategies in emerging economies, Journal of International Management, 18(1), pp. 1-17. http://dx.doi.org/10.1016/j.intman.2011.06.002

22. Richard, O. C., McMillan-Capehart, A., Bhuian, S. N., Taylor, E. C. (2009): Antecedents and consequences of psychological contracts: Does organizational culture really matter? Journal of Business Research Vol. 62, pp. 818-825. http://dx.doi.org/10.1016/j.jbusres.2008.04.001

23. Szöke, J. (2014): Kis- és középvállalatok határon átnyúló gazdasági kapcsolatai kulturális aspektusból. Doktori értekezés, Széchenyi István Egyetem, Győr

24. The Hofstede Center (2015): National culture, Hungary and Austria http://geerthofstede.com/countries.html, Downloaded: 28/12/2015 